Iryna Didenko,

Ph.D., Assistant Professor, Finance, Banking and Insurance Department, Sumy State University,

Sumy, Ukraine

Yana Kryvych,

Ph.D., Associate Professor, Finance, Banking and Insurance Department, Sumy State University,

Sumy, Ukraine

Anna Buriak,

Ph.D., Associate Professor, Finance, Banking and Insurance Department, Sumy State University,

Sumy, Ukraine

\title{
EVALUATION OF DEPOSIT MARKET COMPETITION: BASIS FOR BANK MARKETING IMPROVEMENT
}

Business strategy and market communication of financial intermediaries, including banks require a transformation under the significant impact of the innovation's development and a highly competitive landscape. The article considers bank marketing improvement through evaluation of deposit market competition. Key trends of the deposit market by Ukrainian case were analysed by authors. More than $60 \%$ of the total deposit portfolio of Ukraine is concentrated in 5 largest banks making market highly concentrated. Comparative matrix of the existing approaches and models for assessing the level of competition in the banking market was presented in the paper. Using nonstructural PanzarRosse model (by calculating the H-statistics as an indicator of the level of competition on the market) and input quarterly data on the bank's financial performance in Ukraine for the period 01.01.2005-01.04.2016, four main factors for bank competition level on the deposit market were identified. They include the rate of bank liquidity; factor describing the effectiveness of bank funding strategy; a factor assessing the availability of the bank's reserve funds and a factor that combines all the key indicators of the country's banking system stability (the ratio of equity capital to total assets, the ratio of the volume of customers' deposits to total assets, the ratio of total unpaid assets to assets, the ratio of total administrative expenses of the bank to its assets). Evaluation results point out on the monopolistic competition with frequent deviations towards absolute monopoly or oligopoly on the deposit market of Ukraine. This trend is consistent with the characteristic of the European Union indicating a further reforming of the banking sector in this segment (for example, full implementation of Basel II, Basel III). Suggested and empirically tested approach for evaluation of deposit market competition could expand tools of bank marketing strategies.

Keywords: bank marketing, banks, deposit market, competition, Panzar-Rosse model.

Introduction. Modern trends of technological innovation and digital economy have been considerably influenced on the financial sector by transformation of business strategy and market communication, and definitely of the financial system structure and stability (Cichy, 2016, Dusko Knezevic, 2018, Gavurova,2017; Vasylieva, 2017; Swiatkiewicz, 2018). Moreover, increased competition on financial market leads to an intensification of bank marketing tools to maintain financial indicators of bank business. Effective usage of traditional bank marketing tools requires the evaluation of the market situation and competition as well (Barhaq, 2018, Pimonenko, 2017).

The problem of competition evaluation in the banking system always in the centre of scientific research 
as it plays an important role in the entire financial system. On the one hand, a banking system of any country is an indicator of economic development, on the other - it could become a catalyst for both positive and negative structural changes in the financial system (Karaev, 2017). In this article, we aim to calculate the level of competition in the deposit market of Ukraine for further bank marketing implications.

The issue of assessment of the competition level on the deposit market and in the banking sector, in general, became of great relevance in the post-crisis period of the global economic crisis of $2008-2009$. This event showed the importance of not just possessing information about the market, but also properly management of market position. Competition (monopoly, oligopoly, monopolistic or perfect competition), as an integral part of the market economy, is causing a number of structural phenomena: emergence of various market risks, presence/absence of barriers to the market entry for new institutions, setting an equilibrium market price, policy measures by the market regulator, the presence of systemically important institutions, market concentration and so on.

Choosing the right instrument of bank marketing it is necessary to consider the specifics of the credit and deposit markets functioning: specifics of subjects creating supply and demand on the market, the main product/service (or a group of products/services) that are offered on the market, equilibrium market prices and soon (Zarutska,2018). When we talk about an effective functioning of the deposit market in Ukraine, we mean such market conditions in which there is a positive dynamic of the active attraction of financial funds from customers (individuals as well as business entities) on bank accounts with their equal distribution among all commercial banks at optimal interest rates. Under these conditions, the market should seek to establish a free competition. However, in reality, we have a different situation. Since the deposit market does not exist in isolation from other related markets of the financial system, it has several factors that have an impact on the formation of its competitive environment:

- the presence of other financial institutions that provide alternative choices for customers (insurance companies, investment funds, private pension funds, etc.);

- presence of foreign banks on the market;

- differentiation between commercial banks according to their volumes and specific features of the market policy instruments;

- inability to predict the behaviour of competitors regarding their use of the market policy instruments;

- the existence of barriers to enter and exit the market;

- the intensity in the use of innovations in the marketing of deposit services.

The paper is structured as follows. Section 2 introduces the key tendencies of the deposit market in Ukraine, existing approaches to assessing the level of competition in Ukraine and other countries as a start point for further research, analyzes the advantages and disadvantages of structural and nonstructural models. Section 3 provides a detailed methodology of the Panzar-Rosse model and its specification for the deposit market of Ukraine. Section 4 uses the quarterly data on the financial performance of banks in Ukraine for the period 01.01.2005 - 01.04.2016 for evaluation of the level of competition on the deposit market of Ukraine. Section 5 provides the conclusions of the paper.

Literature review. The key trends of the deposit market in Ukraine. The National Bank of Ukraine (NBU) is one of the key active participants in the realization of these goals. The stage of "cleaning" of the banking system has already brought its results. Firstly, as a result of stress testing in 2014, 35 largest banks were additionally capitalized by the National Bank, secondly, in the period 2014 - 2016, due to a number of reasons, 82 banks were removed from the market, as a result, a total of 100 banks were operating in Ukraine by 09.01.2016. These processes launched the phase of "resetting" of the banking system of Ukraine influencing on the state of the deposit market in particular.

The deposit portfolio of Ukraine in 2008 - 2016 can be represented by the following indicators (Table 1). 
Table 1 - The dynamics of the deposit portfolio of Ukraine in the period 2008 - 2016 (data for the beginning of the period) (The National Bank of Ukraine, 2016)

\begin{tabular}{|l|c|c|c|c|c|c|c|c|c|}
\hline \multirow{2}{*}{ Indicator } & \multicolumn{7}{|c|}{ Years } \\
\cline { 2 - 10 } & 2008 & 2009 & 2010 & 2011 & 2012 & 2013 & 2014 & 2015 & 2016 \\
\hline $\begin{array}{l}\text { Corporate deposits, mIn } \\
\text { UAH }\end{array}$ & 111995 & 143928 & 115204 & 144038 & 186213 & 202550 & 234948 & 261372 & 317626 \\
\hline $\begin{array}{l}\text { Including term corporate } \\
\text { deposits, mIn UAH }\end{array}$ & 54189 & 73352 & 50511 & 55276 & 74239 & 92786 & 104722 & 102527 & 96176 \\
\hline $\begin{array}{l}\text { Retail deposits, mIn UAH } \\
\begin{array}{l}\text { Including term retail } \\
\text { deposits, mIn UAH }\end{array}\end{array}$ & 163482 & 213219 & 210006 & 270733 & 306205 & 364003 & 433726 & 416371 & 389060 \\
\hline
\end{tabular}

Deposit bank portfolio of Ukraine in 2008 - 2016 was mostly represented by the funds of individuals (retail segment), which were much higher than the funds of the corporate segment. Only in 2016, they began to decline (Table 2).

Table 2 - Dynamics of the deposit portfolio of Ukraine in 2016 (data for the beginning of the period) (The National Bank of Ukraine, 2016)

\begin{tabular}{|c|c|c|c|c|c|c|c|c|}
\hline \multirow{2}{*}{ Indicator } & \multicolumn{8}{|c|}{ Years } \\
\hline & Feb & Mar & Apr & May & Jun & Jul & Aug & Sep \\
\hline $\begin{array}{l}\text { Corporate deposits, mln } \\
\text { UAH }\end{array}$ & 325988 & 336999 & 332961 & 336682 & 338017 & 347898 & 351308 & 351843 \\
\hline $\begin{array}{l}\text { Including term corporate } \\
\text { deposits, mIn UAH }\end{array}$ & 97134 & 97261 & 92296 & 97956 & 95629 & 94933 & 96387 & 92090 \\
\hline Retail deposits, mIn UAH & 392028 & 408347 & 403046 & 395154 & 389937 & 395148 & 398927 & 404823 \\
\hline \begin{tabular}{|lrl} 
Including term & retail \\
deposits, & mIn UAH
\end{tabular} & 292030 & 305031 & 300516 & 290803 & 287070 & 285378 & 287812 & 294455 \\
\hline
\end{tabular}

This can be explained by the fact that the banking sector of Ukraine is gradually gaining the confidence of the corporate segment of its customers. In addition, it is also confirmed by the favorable dynamics of the fixed term deposits both in foreign and national currencies. The customers' trust in the country's banking system creates a positive foundation for supporting the banking system's liquidity and intensification of lending activities.

Regarding the characteristics of the deposit portfolio of Ukraine in terms of the foreign exchange component, we have the following picture (Fig. 1).

As we see, the share of deposits in the national currency is more than half of all deposits obtained during $2010-2015$. The exception was the first quarter of 2015 when the share of deposits in the national currency decreased from $54.1 \%$ to $46.6 \%$, which can be explained by the devaluation of Hryvnia against foreign currencies (including the dollar and the euro) as well as the unstable economic situation in the country. Generally, within 5 years, one observes a positive dynamic of attracted deposits.

More than $60 \%$ of the total deposit portfolio of Ukraine is in the 5 largest banks making it possible to assume that the deposit market in Ukraine is highly concentrated. The main problem here may be the fact that according to the latest news published on the site of the National Bank of Ukraine regarding systemically important banks, 3 out of 5 banks, namely "Privatbank", "Oschadbank" and "Ukreksimbank" are systemically important for the whole economy and this presents a threat to the safety of the deposit market. 


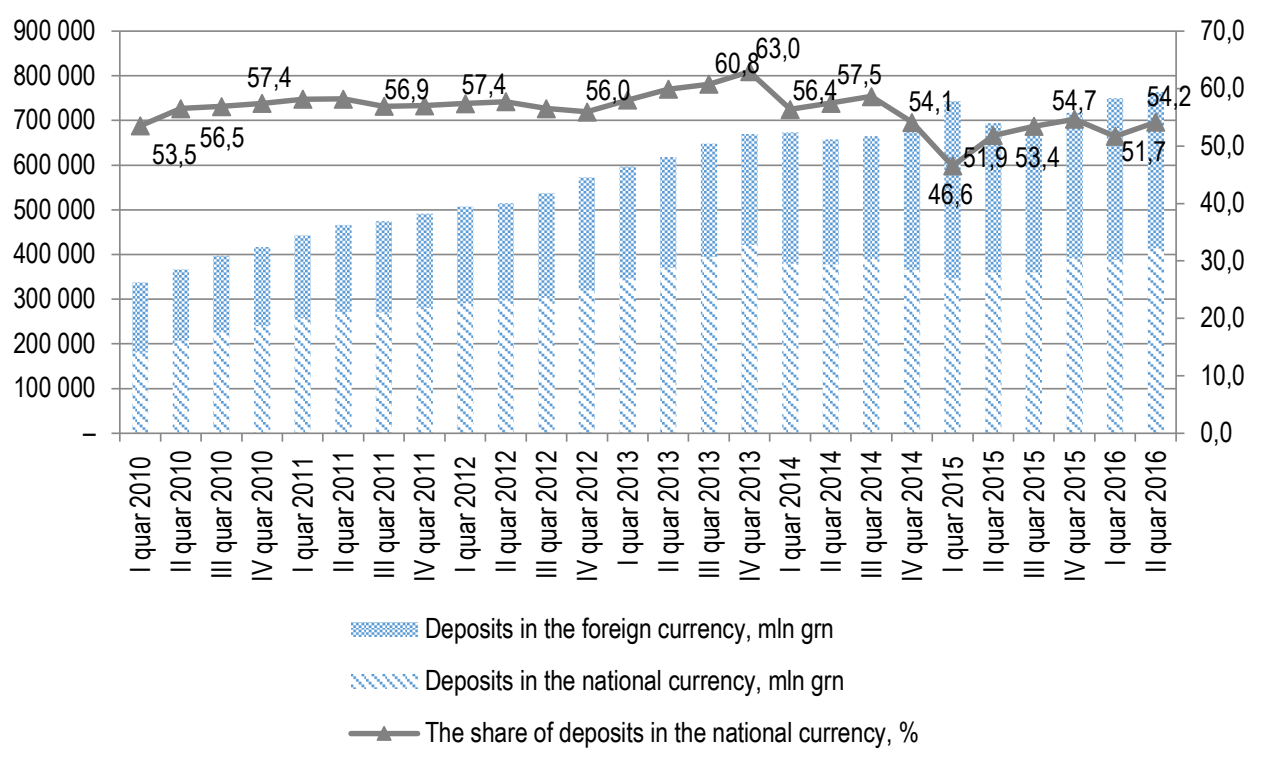

Figure 1 - Dynamics of deposits in the national and foreign currencies during the period 2010 2016 (The National bank of Ukraine, 2016)

Evaluation methods. Some research analysed the level of competition in the banking market as a whole not dividing it into separate segments. For example, in one section of paper Leonov (2009) assesses the level of competition in the banking system of Ukraine using the model of Modesto Barros (1999) According to this model, the country's banking system is represented as a symbiosis of the credit and deposit markets, each of which brings its usefulness from the realized banking services:

$$
\begin{gathered}
U(x)=\sum_{t=1}^{n} \propto_{i} c_{i}-\frac{1}{2}\left(\delta \sum_{i=1}^{n} c_{i}^{2}+2 \omega \sum_{j=1}^{n} c_{i} c_{j}\right)+ \\
\quad+\sum_{i=1}^{n} \mu_{i} d_{i}-\frac{1}{2} \beta\left(\sum_{i=1}^{n} d_{i}^{2}+2 \gamma \sum_{j=1}^{n} d_{i} d_{j}\right)
\end{gathered}
$$

where $U(x)$ - usefulness of banking services; $\propto, \delta, \omega, \mu, \beta, \gamma$ - parameters of the model; $c_{i} c_{j}, d_{i} d_{j}$ the volume of the given credits and received deposits; $i, j-$ a functioning bank, where $i=1, \ldots, n ; j=1, \ldots, n$ ( $\mathrm{n}$ - total number of banks), $i \neq j$.

$$
m=y+\sum_{i=1}^{n} r_{i}^{d} d_{i}+\sum_{i=1}^{n} r_{i}^{c} c_{i}
$$

where $m$ - resources that users spend on goods and services not directly related to the credit and deposit services; $y$-income of consumers; $r_{i}^{d}, r_{i}^{c}$-interest rates on credits and deposits, respectively.

The equation for the assessment of the level of competition of the banking system $(\mathrm{CL})$ according to the Modesto Barros model:

$$
C L=U(x)+m
$$

Thus, it was determined that during the period from 2002 to 2008, the banking system of Ukraine experienced the growth of the competition. The key factor, in this case, was an increase in the number of 
commercial banks operating in that period. Of course, this approach can be used to assess the level of competition, but it does not include a number of other parameters related to banking.

Thus, Xavier (2001) examines the main trends of interdependence between the level of competition and regulation of the banking system, the level of the banking market concentration and the type of competition on it. As a result of the analysis, Xavier states that the contemporary market of banking services is so diverse that it should be considered in terms of its individual segments. Accordingly, the optimal level of competition will depend on the institutional characteristics of the market and other internal and external factors. Each country is characterized by its own optimal level of competition: the developed countries with a high level of information visibility and low social costs are usually characterized by a high level of competition, and for the developing countries and countries with a low level of the economic competition is insignificant.

The problem of the qualitative nature of competition among banks was also studied by Cetorelli (2001). He considered the approaches of different authors on the positive and negative qualities of different types of competition in the banking environment. The key thesis of his study was that whether monopolistic or perfect banking competition, it still has the same positive and negative effects on some aspects of banking. Therefore, the ideal situation is a compromise between the market participants as a result of which an optimal level of competitiveness could be established. Nicola Cetorelli also notes that while regulating the situation in the banking segment it is necessary to consider the impact of institutions on another sector of the economy.

Beregulya S. (2011) in the research of banks' strategy based on the competitiveness as one of the levels, which impacts the development of the banking system, investigates the problem of competition on the deposit market of Ukraine. The paper appeals to the question, whether it is appropriate to assess the general level of competition on the deposit market since this market is characterized by the "mass character" in the provision of services with homogeneous instruments. The answer lays in the specific character of banking. For a bank, as a seller of such an extraordinary product as "deposit services", it is difficult to compete with other banks only by changing the price (interest rate on deposits), because it depends not only on it but also on a number of external factors (discount rate, refinancing rate of commercial banks, maximum lending margins, etc.). In this case, it is necessary to consider a non-price competition (reliability of banks, international financial ratings, additional services, etc.). According to the researcher, it is crucial for ensuring a competitive environment of the deposit market. However, the author does not offer any method for assessing the level of competition, which provides a basis for further research in this area.

Another Ukrainian scientist Gladkyh (2012) also studies the problem of competition in the banking sector of Ukraine. After analyzing the features of the four major models of the market (free competition, pure monopoly, monopolistic competition, and oligopoly), he concludes that both the credit and deposit markets in Ukraine are characterized by free competition with signs of oligopoly. This conclusion was based on the analysis of the number of total assets, credit and deposit portfolios of banks and the author's assumptions. We agree with the researcher that the structure of assets and portfolios can help draw a rough picture of how the competitive environment is formed, but without a statistical interpretation of the level of competition, it is impossible to identify a clear line between free competition and oligopoly. These conclusions are quite interesting and require additional confirmation or refutation by conducting additional research in this area. There are two groups of approaches to assessing the level of competition: structural and nonstructural (Moiseev, 2007).

Structural approaches are based mainly on the assumption that market competition is influenced by its structure, that is, a set of indicators that includes a number of entities of the specific branch, a size of the firm, the degree of product's differentiation and the size of barriers to market entry (Goddard et al., 2001). Within the structural approach, two key hypotheses are distinguished. The first hypothesis of 
Structure-Conduct-Performance (SCP) or the Harvard paradigm (Bain, 1951), stipulates the dependence of the level of competition on the market from the share of a particular market sector and the number of market participants (concentration). Therefore, to assess the competition according to the first hypothesis we use concentration ratios (Herfindahl-Hirschman Index), entropy indices, Gini coefficients, market share, the number of market participants, etc. This hypothesis was used in the period between the First and the Second World Wars, mainly in America to analyse the branch, which at that time was characterized by a high concentration of market power of several monopolistic manufacturers.

Twenty years later, as part of the structural approach, one professor from the University of California put forward another important hypothesis - the hypothesis of Efficient Structure (ES) (Demsetz, 1973). The content of the second hypothesis is different from the previous one and brings to the fore the efficiency of market participants. The more efficient the participants are, the higher their level of concentration and profits. Unlike the previous hypothesis, this hypothesis of Efficient Structure became popular on the European market of banking services.

Having summarized these two hypotheses, we can say that they represent two different positions regarding the assessment of competition on the market. The hypothesis of Structure-ConductPerformance (SCP) was one of the first attempts to explain the nature of the competitive structure of the banking market. It lost its relevance and appropriateness via its superficial character because it is not correct to talk about the competitive position of the bank, which is formed only under the influence of the market structure. With the Efficient Structure (ES) hypothesis, during the study of competition the focus was switched to market players and the efficiency of their functioning; however, the logic was still limited to the degree of market concentration.

Assessing the level of competition by using structural approaches several drawbacks were discovered, one of which is the fact that structural methods cannot detect the influence of hidden factors in assessing the level of competition on the market. In addition, the high level of concentration does not guarantee the presence of market power. Because of this, in the 80s non-structural methods of assessing the level of market competition were used. They made it possible to assess the level of competition in the market based on the behavior of market participants and a number of other factors. The main non-structural models include the models of Barros and Modesto (1999), Bresnahan and Lau (1982), Iwata (1974), Panzar and Rosse (1987) and others.

Researchers often abandon structural approaches in favor of non-structural ones as they do not make it possible to investigate the impact of the hidden factors on market competition. Because of the fact that structural methods are limited to several factors of the research, the results they help to obtain are distorted and do not reflect the real situation on the market. Therefore, to assess the level of market competition, particularly in the banking system, increasingly non-structural methods are used. The list of the most popular of these methods, as well as the pros and cons of each of them, are presented in the supplement in Table 3. As we see, the highest number of positive assessments was received by three models: Barros and Modesto, Bresnahan and Lau, Iwata, Panzar and Rosse. Almost for all positions, they obtained a positive assessment that confirms that they are widely used in evaluating the level of competition in the banking sector. However, for further research, it is necessary to choose one of these models. Because using the Barros and Modesto model requires access to all statistical data, it becomes very sensitive, especially to the local realities when we deal with the situation of closed banking information. In addition, one should also pay attention to the accuracy and reliability of the results obtained through the Barros and Modesto model. Thus, we have chosen two models. The model of Bresnahan and Lau and the model of Panzar and Rosse are the most popular in assessing the level of competition in the banking system. 
Table 3 - The comparative matrix of the existing approaches and models for assessing the level of competition in the banking market (authors' calculations)

\begin{tabular}{|c|c|c|c|c|c|c|c|c|c|c|}
\hline \multirow[b]{2}{*}{ Approach/model } & \multicolumn{10}{|c|}{ Features } \\
\hline & 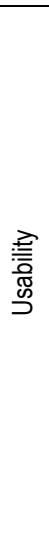 & 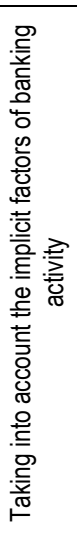 & 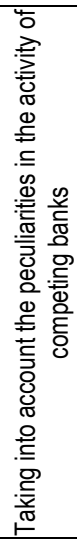 & 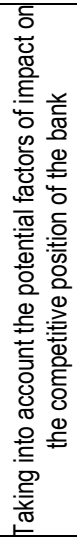 & 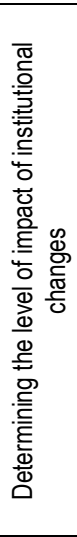 &  &  &  & 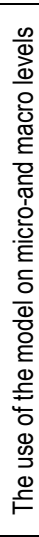 & 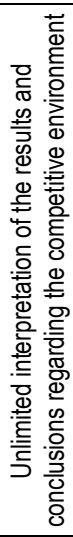 \\
\hline Structural & + & - & - & $+/-$ & - & - & - & $+/-$ & - & - \\
\hline \multicolumn{11}{|l|}{ Non-structural: } \\
\hline Barros and Modesto model & $+1-$ & + & + & + & + & $+/-$ & - & + & + & + \\
\hline Iwata model & - & + & + & + & + & + & - & $+/-$ & + & - \\
\hline Lerner Index & $+1-$ & + & + & + & $+/-$ & - & - & $+/-$ & + & - \\
\hline Boone criterion & $+/-$ & + & + & + & $+/-$ & $+/-$ & - & $+/-$ & + & $+/-$ \\
\hline The parameter of sustainable profitability & $+1-$ & + & + & + & $+/-$ & $+/-$ & - & $+/-$ & + & $+/-$ \\
\hline Bresnahan and Lau model & - & + & + & + & + & + & + & $+/-$ & + & + \\
\hline Panzar and Rosse model & $+/-$ & + & + & + & + & + & + & $+/-$ & + & + \\
\hline
\end{tabular}

In our study, we focus on the conditions of the deposit market in Ukraine. Therefore, choosing the model for assessing the level of competition it is necessary to consider the internal peculiarities of the banking activity and its regulation. For this reason, the disadvantages of the model of Bresnahan and Lau in Table 3, overweight advantages over the model of Panzar and Rosse. After analyzing the available data from the Ukrainian public information resources, we have come to the conclusion that it is insufficient to use the model of Bresnahan and Lau. We will use Panzar and Rosse model for the further research of the level of competition in the deposit market of Ukraine. Compared to other non-structural models the fundamental advantages of the Panzar and Rosse model include the following features: 1 ) it is a universal instrument for assessing the level of competition in different countries (with different levels of economic development), which makes it possible to compare the results and make inter-regional analysis; 2) it makes it possible to assess the level of competition on a separate market segment and of the whole market in general; 3) it is aimed at maximizing profits in a competitive environment; 4) using this model, there is no problem with input information, which is freely available.

Based on the comparative matrix of existing approaches and models for assessing the level of competition in the banking market, it was determined that for research of the level of competition in the deposit market of Ukraine should be used the model of Panzar and Rosse.

Data and Methodology. To assess the level of competition in the deposit market we will use the model of Panzar-Rosse (1987). For this study, as input data, we used the quarterly data on the financial performance of banks in Ukraine for the period 01.01.2005 - 01.04.2016.

The general view of the model of Panzar-Rosse that used for evaluation of the competition level in the banking market, is presented below. 


$$
\ln (P R)=\alpha_{0}+\alpha_{1} \times \ln (F I P)+\alpha_{2} \times \ln (B S F)+\alpha_{3} \times \ln (T A)+\varepsilon
$$

where $\alpha_{0}$ is a constant, a free term of the model; $\alpha_{1}, \alpha_{2}, \alpha_{3}$ - coefficients of the model; $P R$ - interest income of the bank; FIP - a variable that reflects the cost of the factor of production; BSF - a variable which describes the specific banking factors; $T A$ - total assets; $\varepsilon$ - the value of random error.

To assess the level of competition according to the model of Panzar-Rosse it is necessary to calculate the indicator of $H$-statistics. It is defined as the sum of indicators $\alpha$ with the variables FIP and BSF.

The indicator of $H$-statistics may take different values, which are interpreted differently:

$$
\left\{\begin{array}{l}
\text { Hstat } \leq 0, \text { perfect monopoly or short-term oligopoly } \\
\text { Hstat }=0, \text { perfect competition or natural monopoly on the market with perfect competition } \\
0<\text { Hstat }<1-\text { monopolistic competition with free-entry equilibrium }
\end{array}\right.
$$

It should be noted that if the indicator of $\mathrm{H}$-statistic is not equal and higher than 0 , it can be argued that there is equilibrium on the market, if it is equal and smaller than 0 , there is no equilibrium.

To formalize the factors influencing the level of competition in the deposit market of Ukraine the following indicators of banking activity have been chosen:

Active - an indicator of the activity scale of the bank (the ratio of bank assets to its total liabilities minus shareholders' equity (everything the bank owes to other people / other banks), \%);

Fund - factor which describes the cost of the fund (the ratio of interest expenses of the bank to the amount of its borrowed funds);

Res - a factor which helps assess the availability of reserve funds to the bank to cover credit arrears (the ratio of reserves to cover credit arrears to its total assets);

$B S F$ - a group of major indicators that describe the country's banking activity (BSF1- the ratio of equity capital to total assets; BSF2 - the ratio of customer deposits to total assets; BSF3 - the ratio of the earning assets to liabilities minus shareholders' equity (everything the bank owes to other people / other banks); BSF4 - the ratio of the non-earning assets to total assets; BSF5 - the ratio of the total administrative expenses of the bank to its total assets).

These indicators were selected so that the maximum consistent with the terms of the Panzar-Rosse model, as well as possible, reflect the specifics of the banking system of Ukraine and deposit market particularly.

Since Ukraine has a high level of inflation during the period, real interest rates would have a negative value but in this research, we interpret all results using the nominal level of performance.

Thus, we have the following model of Panzar-Rosse to formalize the factors influencing the level of competition on the deposit market in Ukraine:

$$
\ln (P R)=\alpha_{0}+\alpha_{1} \times \ln (\text { Activ })+\alpha_{2} \times \ln (\text { Fund })+\alpha_{3} \times \ln (\text { Re s })+\alpha_{4} \times \ln (B S F)+\varepsilon(6)
$$

where $\alpha_{0}$ is a constant, a free term of the model; $\alpha_{1}, \alpha_{2}, \alpha_{3}, \alpha_{4}$ - coefficients of the model; $\varepsilon$ - the value of random error.

Given the task of our research, to assess the level of competition on the deposit market of Ukraine we use the following equation to determine the value of $\mathrm{H}$-statistics as the sum of the coefficients at variables Activ, Fund, Res as they determine the level of competition in the deposit market of Ukraine and others variables as control:

$$
H_{\text {stat }_{i}}=\sum_{k=1}^{3} \alpha_{k i}
$$


Empirical analysis and results. Based on the model (6) and by using the instrument "Multiple regression" of the software package for the analysis of statistical data STATISTICA, we have received 45 different models. These models were used to calculate the value of $\mathrm{H}$-statistic (Table4).

For better visualization of the obtained results for the indicator of $\mathrm{H}$-statistic, we present it graphically (Fig. 2).



Figure 2 - Dynamics of changes of $H$-statistics on the deposit market in Ukraine according to the

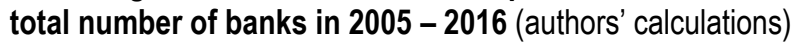

During analysed 11 years, the deposit market in Ukraine, like its banking system as a whole, experienced a number of structural changes due to the economic turmoil of $2008-2009$, as well as internal and external geopolitical problems. In addition, the concentration of assets of the entire banking system and the deposit portfolio in 25 banks did not contribute to establishing a favourable competitive environment in the banking sector. As a result, during the analysed period there is a presence of monopolistic competition on the deposit market of Ukraine with frequent deviations towards absolute monopoly or oligopoly. By the way, this trend is characteristic for the European Union indicating a further reforming of the banking sector in this segment (for example, full implementation of Basel II, Basel III).

As it can be seen from Fig. 2, H-statistics has an oscillatory and unstable character. This is confirmed by the chart showing both sharp drops and rises, which are particularly evident during the global crisis of 2008 - 2009. The maximum value of $\mathrm{H}$-statistics on the deposit market of Ukraine, when it approached the state of perfect competition (0.485), was in the third quarter of 2011. This period, according to the National rating agency "Ryurik", was marked by an increase in fund balances of individuals in Ukrainian banks by $10.8 \%$, indicating a gradual return of confidence in the banking system. However, this situation was short-lived, as at the beginning of the next year the values of the indicator of $\mathrm{H}$-statistics again reached 
zero and became uneven. Regarding the minimum value of $\mathrm{H}$-statistics $(-1.031)$, it took place in the fourth quarter of 2015.

Table 4 - Calculated values of $\mathrm{H}$-statistic for the deposit market of Ukraine for the period $2005-2016$ (authors' calculations)

\begin{tabular}{|c|c|c|c|}
\hline № & Period & Number of banks & Value Hstat \\
\hline 1 & I quarter2005 & 161 & 0.141526 \\
\hline 2 & II quarter2005 & 162 & 0.364838 \\
\hline 3 & III quarter2005 & 163 & -0.00727 \\
\hline 4 & IV quarter2005 & 163 & 0.09569 \\
\hline 5 & I quarter2006 & 164 & 0.148328 \\
\hline 6 & II quarter2006 & 166 & 0.047036 \\
\hline 7 & III quarter2006 & 166 & -0.84227 \\
\hline 8 & IV quarter2006 & 169 & 0.007757 \\
\hline 9 & I quarter2007 & 173 & -0.03328 \\
\hline 10 & II quarter2007 & 173 & -0.03328 \\
\hline 11 & III quarter2007 & 173 & -0.26006 \\
\hline 12 & IV quarter2007 & 173 & 0.030176 \\
\hline 13 & I quarter2008 & 176 & -0.21585 \\
\hline 14 & II quarter2008 & 178 & 0.129449 \\
\hline 15 & III quarter2008 & 181 & -0.28028 \\
\hline 16 & IV quarter2008 & 182 & -0.57651 \\
\hline 17 & I quarter2009 & 182 & -0.66156 \\
\hline 18 & II quarter2009 & 184 & -0.91698 \\
\hline 19 & III quarter2009 & 182 & -0.09541 \\
\hline 20 & IV quarter2009 & 179 & 0.356106 \\
\hline 21 & I quarter2010 & 175 & -0.68384 \\
\hline 22 & II quarter2010 & 176 & -0.65719 \\
\hline 23 & III quarter2010 & 176 & -0.56697 \\
\hline 24 & IV quarter2010 & 175 & 0.306918 \\
\hline 25 & I quarter2011 & 176 & 0.245349 \\
\hline 26 & II quarter2011 & 176 & 0.368327 \\
\hline 27 & III quarter2011 & 175 & 0.485329 \\
\hline 28 & IV quarter2011 & 175 & 0.45769 \\
\hline 29 & I quarter2012 & 174 & -0.26774 \\
\hline 30 & II quarter2012 & 176 & -0.07338 \\
\hline 31 & III quarter2012 & 175 & 0.240736 \\
\hline 32 & IV quarter2012 & 175 & 0.422617 \\
\hline 33 & I quarter2013 & 175 & -0.20701 \\
\hline 34 & II quarter2013 & 176 & 0.050732 \\
\hline 35 & III quarter2013 & 178 & 0.163528 \\
\hline 36 & IV quarter2013 & 180 & 0.381873 \\
\hline 37 & I quarter2014 & 181 & -0.11624 \\
\hline 38 & II quarter2014 & 173 & 0.204478 \\
\hline 39 & III quarter2014 & 166 & 0.184885 \\
\hline 40 & IV quarter2014 & 158 & 0.197099 \\
\hline 41 & I quarter2015 & 133 & -0.18141 \\
\hline 42 & II quarter2015 & 127 & 0.447397 \\
\hline 43 & III quarter2015 & 123 & -0.4916 \\
\hline 44 & IV quarter2015 & 113 & -1.03086 \\
\hline 45 & I quarter2016 & 113 & -0.37757 \\
\hline
\end{tabular}

During that period, the number of banks on the market dropped to 113 - a record for the past 10 years. This led to the panic among the population and redistribution of financial funds among banks. A negative 
sign near the value of the $\mathrm{H}$-statistics indicator in this period shows the non-equilibrium state on the deposit market as evidenced by an increase in this indicator in the next quarter to the mark $(-0.377)$ with an unchanged number of operating banks.

In this research, there is the identification of the link between the level of competition in the deposit market of Ukraine and the total number of banks present in the banking system of Ukraine. Given the results, we should say that there is not a tight link. This is due to the lack of bright dynamics of change in the number of operating banks during $2005-2013$ years. During this time the level of competition in the market fluctuated widely. On the other hand, when the banking system has entered a period of "purification" and the number of operating banks began to decline rapidly, competition initially remained at the same level of monopolistic competition, then rose sharply, and finally equally abruptly struck down (to a level even lower than compared to the crisis period of 2008 - 2009 years.) - the market returned to oligopoly. That is, the number of operating banks in the banking system of Ukraine has an impact on market competition, but it is not decisive.

Conclusions. In the context of innovation technologies development and competitive environment on the financial market, it was found that task of assessing the level of competition both for the whole banking system and for the deposit market, in particular, is an important aspect during the implementation of bank marketing strategy. Researchers offer different approaches to assessing the level of competition. Each of these approaches varies depending on the factors that are taken as a basis for the analysis and the specific features of the market. Today all approaches to assessing the level of competition are divided into two groups: structural and not structural. Given the strengths and weaknesses of these approaches, in the recent years, researchers increasingly use non-structural methods of assessing the level of market competition. In this study, to formalize the factors influencing the level of competition in the deposit market of Ukraine, we used one of the non-structural models - the model of Panzar-Rosse.

Once we have analyzed the latest trends on the deposit market of Ukraine identifying the major problems that exist on it, we have formed a set of factors that, in our opinion, affect the level of competition. Within this model four main factors were identified: liquidity of the bank; a factor which describes the effectiveness of funding bank activity; a factor which helps assess the availability of the bank's reserve funds and a factor that combines all the key indicators of the country's banking system stability (the ratio of equity capital to total assets, the ratio of the volume of customers' deposits to total assets, the ratio of total unpaid assets to assets, the ratio of total administrative expenses of the bank to its assets). The study was conducted based on the quarterly data on the financial performance of Ukrainian banks for the period 01.01.2005-01.04.2016.

After a series of estimations, we obtained 45 values of the indicator of $H$-statistic as an indicator of the level of competition on the market. The analysis of this indicator leads to the conclusion that over the past 11 years on the deposit market of Ukraine, we can observe monopolistic competition with frequent deviations towards absolute monopoly or oligopoly. Suggested and empirically tested approach for evaluation of deposit market competition could expand tools of bank marketing strategies.

Ashton, J. (2001) A test of perfect competition in the UK retail-banking deposit market, The Services Industries Journal, Volume 21, pp. 119- 132. DOI: $10.1080 / 714005052$

Bain, J. (1951) Relation of Profit Rate to Industry Concentration, Quarterly Journal of Economics, No. 65, pp. 293-324. DOI: 10.2307/1882217.

Barhaq, Ab. R., Radchenko, Ol. Optimization of Bank Expenses on Marketing Communications. (2018). Financial Markets, Institutions and Risks, 2(1), 5-14.

Barros, F. (1999) Portuguese banking sector: a mixed oligopoly?, International Journal of Industrial Organization, No. 17, pp. 72 - 86. DOI: 10.1016/S0167-7187(97)00064-7.

Barth, J., G. Caprio, and R. Levine (2000) Banking systems around the world: Do regulation and ownership affect performance and stability? in Prudential Supervision: What Works and What Doesn't, Frederic Mishkin (ed.), Cambridge, MA: National Bureau of 
Economic Research Press. DOI: 10.1596/1813-9450-2325.

Beregulya, S. (2011) Planning of Development in Bank taking into account the competitive environment, Visnyk of the National bank of Ukraine, No. 2 (180), pp. $40-43$ (in Ukr).

Bresnahan, T. F. (1982) "The Oligopoly Solution Concept is Identified", Economic Letters, No. 10, pp. 87 - 92. DOI: 10.1016/0165-1765(82)90121-5.

Cetorelli, N. (2001) Competition among bank: Good or bad? Federal Reserve Bank of Chicago. Economic Perspectives, No. 20, pp. $38-48$

Cichy J., Gradoń W. (2016) Innovative economy, and the activity of financial market institutions. Case of Poland, Journal of International Studies, Vol. 9, No 1, pp. 156-166. DOl: 10.14254/2071-8330.2016/9-1/11

Demsetz, H. (1973) Information and efficiency: Another viewpoint, Journal of Law and Economics, No. 10, pp. 1-22. DOI: 10.1086/466657.

Dusko Knezevic, (2018). Impact of Blockchain Technology Platform in Changing the Financial Sector and Other Industries, Montenegrin Journal of Economics, Economic Laboratory for Transition Research (ELIT), vol. 14(1), pages 109-120.

Drobyshevskyj, S. (2006) An Analysis of Competition in the Russian Banking Sector. Moscow: IEPP (in Rus).

Gavurova, B., Kocisova, K., Kotaskova, A. (2017) The Structure - Conduct - Performance Paradigm in the European Union Banking, Economics and Sociology, 10(4), 99-112. doi:10.14254/2071-789X.2017/10-4/8

Girna, O.Y. (2014) Descriptive and models for assessing the banking market in the European Union and Ukraine Finsovyi prostir, No. 4 (16) (in Ukr).

Gladkyh, D. (2012) The conditions of competition in the Ukrainian banking market, Visnyk of the National bank of Ukraine, No. 9 (199), pp. $9-13$ (in Ukr).

Goddard, J., Molyneux P. and Wilson J. (2001) European Banking: Efficiency, Technology, and Growth, London: John Wiley and Sons.

Hannan, T. H., and J N. Liang, (1993) "Inferring market power from time-series data", International Journal of Industrial Organization, vol.11, pp. 205-218.

Iwata, G.(1974) Measurment of Conjectural Variations in Oligopoly, Econimetrica, № 42, pp. 947 - 966. DOI: 10.2307/1913800. Karaev, A., Melnichuk, M., Guev, T. \&Mentel, G. (2017) Stability analysis of the banking system: a complex systems approach, Journal of International Studies, 10(3), 273-284. doi:10.14254/2071-8330.2017/10-3/20

Lau, L. (1982) On Identified the Degree of Competition from Industry Price and Output Data, Economics Letters. No 10, pp. 87 - 92. DOI: 10.1016/0165-1765(82)90122-7.

Leonov, S. V. (2009) The investment potential of the banking system of Ukraine [monograph] - Sumy: SHEI «UABNBU».

Lyulyov, O., Chortok, Y., Pimonenko, T., \& Borovik, O. (2015). Ecological and economic evaluation of transport system functioning according to the territory sustainable development. International Journal of Ecology and Development, 30(3), 1-10.

Mamonov, M.E. (2010) Modeling of the competition in the Banking sector of Russia Using Panzar - Rosse model: Theoretically and Applied aspects, Bankovskoye delo, No. 11, pp. 17-24 (in Rus).

Moiseev, S.R. (2007) The realities of monopolistic competition in the Russian banking sector, Sovremennaia konkurentciia, No.

1 (1), pp. 14 - 25 (in Rus).

National Council of reform. Financial Sector Reform.[Retrieved 2016-11-10] Available at

:http://reforms.in.ua/ua/reforms/reforma-finansovogo-sektoru (in Ukr).

Panzar, J. C., Rosse J. (1987) Testing for Monopoly Equilibrium, Journal of Industrial Economics, No. 25, pp. 443 - 456. DOI 10.2307/2098582

Pimonenko, T., Radchenko, O., Palienko, M. (2017). Efficiency of marketing communications in banks. Business Ethics and Leadership, 1(2), 55-61. Doi: 10.21272/bel.1(2).55-61.2017

Shaffer, S. (1998) The winner's curse in banking, Journal of Financial Intermediation, Vol. 7, No. 4, pp. 359 - 392. DOI: 10.1006/jin.

Swiatkiewicz, O. (2018) Market Communication: Ethical and Praxeological Dimensions, Economics \& Sociology, 2 (11), 84 199. doi 10.14254/2071-789X.2018/11-2/13

The banking system of Ukraine: results of 9 months of 2011 and key development trends / National rating agency «Rurik». [Retrieved 2016-11-12] Available

http://rurik.com.ua/documents/research/bank_system_tendency_\%D0\%86\%D0\%86\%D0\%86_\%D0\%BAv_2011_ukr.pdf (in Ukr).

The information agency «Interfax Ukraine», Meetings of the Finance Committee of Verkhovna Rada of Ukraine. [Retrieved 2016-11-12] Available at :http://interfax.com.ua (in Ukr).

The National Bank of Ukraine (2005-2016). Deposits of depository corporations (excluding National Bank of Ukraine) 2005 2016. [Retrieved 2016-11-20] Available at :http://www.bank.gov.ua/control/uk/publish/article?art_id=24338412\&cat_id=12063884 (in Ukr).

The National Bank of Ukraine (2005-2016). Information about financial statements of banks in Ukraine 2005 - 2016. [Retrieved 2016-10-10] Available at :http://www.bank.gov.ua/control/uk/publish/category?cat_id=64097 (in Ukr).

The National Bank of Ukraine (2005-2016). Key indicators of banks in Ukraine 2005 - 2016. [Retrieved 2016-10-10] Available at: https://bank.gov.ua/control/uk/publish/article?art_id=34661442\&cat_id=34798593 (in Ukr).

The National Bank of Ukraine (2005-2016). Reorganization and liquidation. [Retrieved 2016-11-10] Available at: 
https://bank.gov.ua/control/uk/publish/article?art_id=75535\&cat_id=17823466 (in Ukr)

Vasylieva, T., Leonov, S., Kryvych, Ya., Buriak A. (2017) Bank 3.0 concept: global trends and implications, Financial and credit activity: problems of theory and practice, № 22 (1), 4-10.

Xavier, V. (2001) Competition in the changing world of banking, Oxford review of economic policy, Vol. 17, No. 4, pp. 535 547. DOI: 10.1093/oxrep/17.4.535

Zarutska El. (2018). Structural-functional analysis of the Ukraine banking system. Financial Markets, Institutions and Risks, 2(1), 79-96.

I.B. Діденко, к.е.н., Сумський державний університет (Суми, Україна);

Я.М. Кривич, к.е.н., доцент, Сумський державний університет (Суми, Україна)

A.B. Буряк, к.е.н., доцент, Сумський державний університет (Суми, Україна).

Оцінка конкуренції на депозитному ринку: основа для удосконалення банківського маркетингу

В умовах суттєвого впливу інновацій та появою висококонкурентного середовища бізнес-стратегія та ринкові комунікації фінансових посередників, включаючи банки, потребують трансформації. у статті розглядається напрям удосконалення банківського маркетингу через оцінку конкуренції на депозитному ринку. Для цього було проаналізовано основні тенденції розвитку депозитного ринку на прикладі України. Емпірично визначено, що більще $60 \%$ загального депозитного портфеля України зосереджено в 5 найбільших банках, що робить ринок висококонцентрованим. У роботі було розроблено порівняльну матрицю існуючих підходів та моделей для оцінюваня рівня конкуренції на ринку банківських послуг. Обгрунтовано, що найбільш доцільним слід вважати використання моделі Панзара-Росса (шляхом розрахунку Нстатистики як показника рівня конкуренції на ринку) на основі щоквартальних даних щодо фінансових показників банків в Україні за період з 01.01.2005 р. по 01.04.2016р. Ключовими чинниками для оцінювання рівня конкуренції на ринку депозитів було визначено рівень банківської ліквідності; фактор, що описує ефективність стратегії фрінансування банків; фактор що характеризує наявність резервних фондів банку та фактор, який поєднує в собі всі основні показники стабільності банківської системи країни (співвідношення власного капіталу до загальних активів, співвідношення обсягу депозитів клієнтів до загальних активів, співвідношення загальної суми несплачених активів до активів, співвідношення загальних адміністративних витрат банку до його активів). Результати оиінки свідчать про монополістичну конкуренцію з частими відхиленнями до абсолютної монополії або олігополії на депозитному ринку України. Ця тенденція відповідає ситуації на ринку Європейського Союзу, що свідчить про подальше реформування банківського сектору в иьому сегменті (наприклад, повне впровадження Базель II, Базель III). Запропонований та емпірично перевірений підхід для оцінювання конкуренції на ринку депозитів може розширити інструментарій маркетингових досліджень та стратегічного аналізу банків.

Ключові слова: банківський маркетинг, банки, ринок депозитів, конкуренція, модель Панзара-Россе. 